\title{
球状ボイドを導入した窒化ケイ素セラミックスの破壊強度
}

\author{
岡田明・広崎尚登 \\ (日産自動車 (株) 中央研究所材料研究所)
}

\section{Fracture Strength of Silicon Nitride Ceramics with Spherical Voids}

\author{
Akira OKADA and Naoto HIROSAKI
}

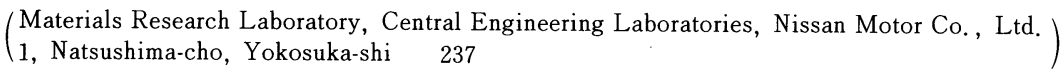

Void size dependency of the fracture strength of silicon nitride ceramics was studied to develop a failure model from a void. Fracture strength of silicon nitride ceramics including spherical voids generally decreased with increasing void size. A model of a spherical woid with a circumferential crack was applied to estimate the crack extension. The length of the circumferential crack was calculated to be about $30 \mu \mathrm{m}$, which corresponded to 10-15 times of the average grain diameter. Thus, it was assumed that the microcrack extension from a void occurred during loading before the maximum load was reached. Considering the transition of the fracture toughness from single-crystal to polycrystalline, it was concluded that the critical crack extension from the void was attributed to the dependence of the fracture toughness on crack size/grain size ratio.

[Received April 16, 1986]

Key-words: Silicon nitride, Fracture toughness, Void, Fracture strength, Crack propagation mechanism, Fracture source

\section{1. 緒言}

セラミックスの破壊起点を調べると様々の欠陥を発見 することができる．これらの欠陥はセラミックスの疲労 や破壊強度を支配するので, 久陥生成の制御は構造材料 として信頼性の高いセラミックスを製造するときの重要 な要素技術になり得る. 強度を支配する代表的な欠陥と しては, 表面傷, ボイド, 異物, 巨大粒子等が知られて いるが，このような久陥が強度に及ぼす影響及びその機 構については十分に知られていない。例えば，ボイドが 破壊強度を支配する機構についても, ボイドの曲率によ る応力集中のみでは，その破壊応力を説明することは困 難であり，ボイドの周囲にき裂が発生して強度低下が生 ずるものと考えられている，ボイドの周囲に円環状のき 裂が発生したときの $K_{\mathrm{I}}$ を算出する方法が提案 ${ }^{1) ~ 6) ~ さ れ ~}$ ているが，そのき裂の大きさについての理論的根拠は明 らかではない．ボイド周囲に発生するき裂の大きさ（図 1) としては, 従来, 粒径にほぼ等しい7と考えられて いたが, Heinrich と Munz $z^{8)}$ は円環状き裂の大きさ $\left(L_{\mathrm{c}}\right)$ を粒径 $(G)$ と等しくすると, 実測した破壊応力よりか なり大きな值が算出されるので, むしろ, ボイドと同じ 半径を有する半円状の表面傷と近似した方が妥当な結果 を与えると報告している.しかし, Seshadri と Srinivasan ${ }^{9}$ は円環状き裂を伴うボイドモデルの方が, 破壊応力と欠陥の大きさの関係のばらつきを小さくする と報告し, Baratta ${ }^{10)}$ は $L_{c} \approx G$ の近似は必ずしも正しい と限らず， $L_{\mathrm{c}}$ は $K_{\mathrm{IC}}$ 及びボイドの大きさに影響される
と指摘している. Kirchner とGruver ${ }^{11)}$ は, 破面観察に より，アルミナの $L_{\mathrm{c}}$ がへき開き裂長さの $0.40 \sim 0.58$

$\sigma$
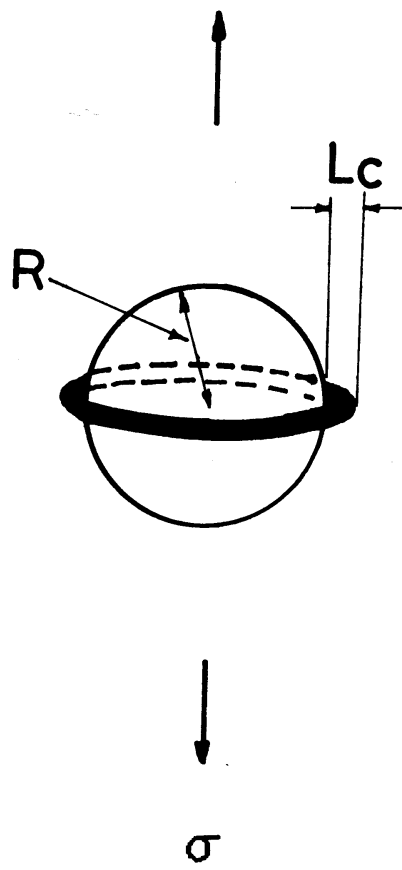

Fig. 1. A spherical void with a circumferential crack at its equator. 
に相当することを指摘しているが，その大きさは $G$ よ りかなり大きい. Heinrichと Munz ${ }^{12)}$ は, 反応焼結公 化ケイ素について破壊強度とボイドの大きさから $L_{\mathrm{c}}$ を 算出すると，1〜10 G に相当すると報告している.

そこで，本研究においては，球形のボイドを含有する 窒化ケイ素セラミックスを用いて，ボイドの破壊応力に 及ぼす影響とそれによる破壊機構の検討を行うことを目 的とした。

\section{2. 実験方法}

イットリアとアルミナを添加して窒化ケイ素粉末を湿 式混合したのち，75〜150 $\mu \mathrm{m}$ の粒径を有する球形のプ ラスチック（三菱化成製液体クロマトグラフィー用充て ん剤 MCi-GEL CWK100P) を加えてかくはん混合し， 乾燥して混合粉末を作製した。これを乾式成形し，空気 中で $500^{\circ} \mathrm{C}$ まで加熱してプラスチック球を然焼除去し たのち, $1700^{\circ} \mathrm{C}$ の窒素中で 1 時間焼成した。 また，一 部の焼結体は, 更に $1700^{\circ} \mathrm{C}$ の窒素中にて 1500 気圧, 1 時間の HIP 処理を施した.

得られた焼結体は幅 $4 \mathrm{~mm}$, 厚さ $3 \mathrm{~mm}$, 長さ $40 \mathrm{~mm}$ の形状に研削加工を施し，JIS R 1601 に準拠した 4 点 曲げ試験を行った．曲げ試験片の破面については走査型 電子顕微鏡 $(S E M)$ による観察を行い，導入した球状 欠陥により破壊が生じたものについては，その球の直径 を測定した。

\section{3. 結 果}

常圧焼結体と HIP 処理体の密度はそれぞれ 3.23 $\mathrm{g} / \mathrm{cm}^{3}$ と $3.30 \mathrm{~g} / \mathrm{cm}^{3}$ であり, HIP 処理による密度上昇

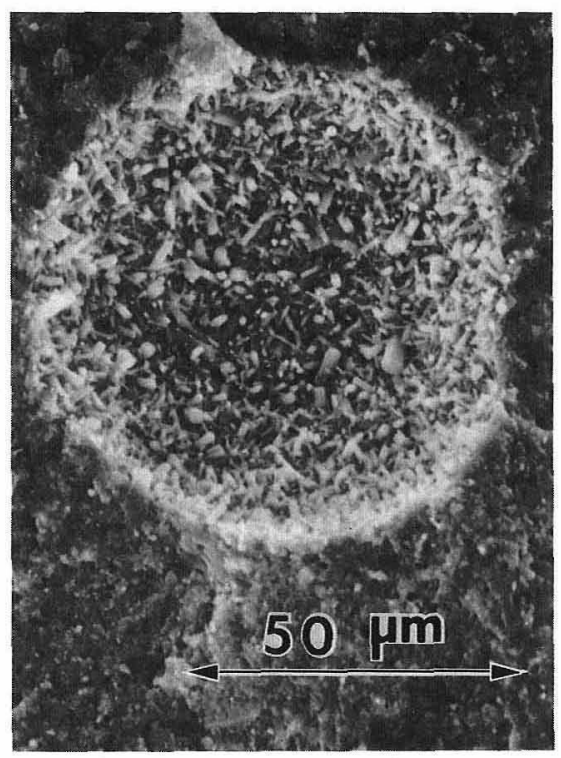

Fig. 2. A spherical void as a fracture source of silicon nitride ceramics.

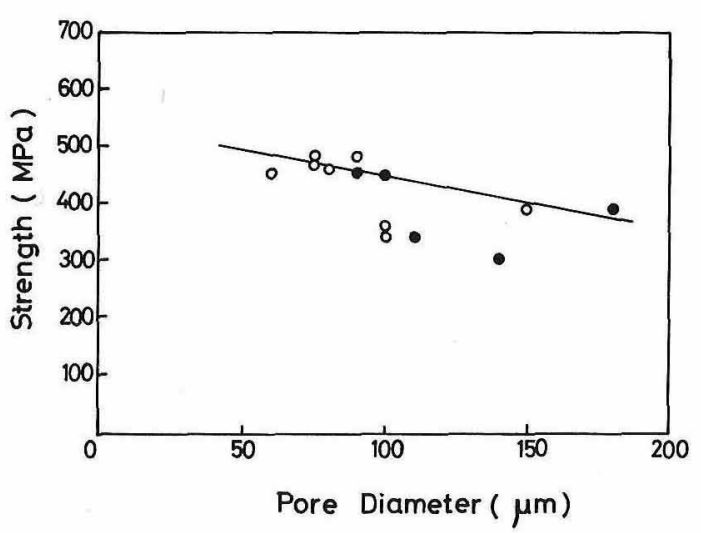

Fig. 3. Effects of the pore diameter on the fracture strength of silicon nitride ceramics.

: Sintered silicon nitride,

$\mathrm{O}$ : Post-HIP'ed silicon nitride

が認められた.しかし，4点曲げ強さについてはそれぞ れ $473 \pm 34 \mathrm{MPa}$ と $451 \pm 55 \mathrm{MPa}$ であり, H1P 処理に よる増加は認められなかった，単一の球状ボイドからな る代表的な破壊起点を図 2 に示す. 球状粒子の内面は柱 状組織の発達した凹凸の激しい様相を呈しているが，偏 析等については認めらない. HIP 処理により組織は若 干粗大化するが，ボイドの形態については，ほとんど影 響が認められなかった。破壊起点が単一の球状ボイドで あるときには，4点曲げ強さから破壊起点における破壊 応力を計算し, 球状ボイドの大きさに対してプロットし た（図３）. 球状ボイドが大きいときには破壊応力が低 くなる傾向にあり, HIP 処理の有無にかかわらず，よ い相関関係が認められたが，一部の試料ではその相関か ら逸脱して約 $100 \mathrm{MPa}$ 低い破壊応力が測定された.

\section{4. 考察}

窒化ケイ素セラミックスの破壊起点に見いだされるボ イドの大きさが増すと破壊応力は低下する㑯向が羿めら れた. ボイドの破壊力学的モデルとしては, 半だ円形の 表面傷に近似する方法 ${ }^{81}{ }^{91}$ と円環状き裂を伴うボイドモ デル(1) 6) が提案されているが, 前者の方法は近似の根拠 が不明りょうであり ${ }^{101 一}$ 般的に正しい方法とは考えにく い. 後者のモデルによる $K_{\mathrm{I}}$ の近似解について, Baratta ${ }^{11,5)}$ は次のような式を提案している.

$$
\begin{aligned}
K_{\mathrm{I}} / \sigma \sqrt{\pi L}= & {\left[c-k\left(\tan ^{-1} L / R\right)^{m}\right]\left\{\frac{1}{2(7-5 \nu)}\right.} \\
& \cdot\left[(4-5 \nu)\left(\frac{1}{L / R+1}\right)^{3}\right. \\
& \left.\left.+9\left(\frac{1}{L / R+1}\right)^{5}\right]+1\right\}
\end{aligned}
$$

ここで, $c=1.12, m=1.00, k=0.30, \nu$ はポアソン比, $L$ は円環状き裂の長さ, $R$ はボイドの半径である. 
Table 1. Circumferential crack length surrounding voids in silicon nitride ceramics, calculated from Baratta's equation.

Sample No. 6431-6444: Sintered silicon nitride, Sample No.6412-6424: Post-HIP'ed silicon nitride

\begin{tabular}{|c|c|c|c|c|c|c|c|}
\hline Sanple No. & $\sigma\left(\begin{array}{ll}\mathbf{P} & \mathrm{a}\end{array}\right)$ & $2 \mathrm{R}($ & $\mu \mathrm{m})$ & $\mathbf{K}_{\mathrm{I}} \mathrm{c} / \sigma \mathbf{R}^{1 / 2}$ & $\mathbf{L}$ & $(\mu$ & m) \\
\hline 6431 & 312 & 14 & 0 & 1.801 & & 10 & 0 \\
\hline 6437 & 452 & 9 & 0 & 1.550 & & & 3 \\
\hline 6439 & 390 & 18 & 0 & 1.270 & & & 2 \\
\hline 6442 & 341 & 11 & 0 & 1.858 & & & 7 \\
\hline 6444 & 455 & 10 & $\mathbf{0}$ & 1.461 & & & 7 \\
\hline 6412 & 343 & 10 & 0 & 1. 937 & & & 0 \\
\hline 6413 & 468 & 8 & 0 & 1. 588 & & & 3 \\
\hline 6415 & 390 & 15 & 0 & 1. 392 & & & 0 \\
\hline 6416 & 360 & 10 & 0 & 1.846 & & & 7 \\
\hline 6417 & 480 & 9 & 0 & 1.460 & & & 4 \\
\hline 6418 & 472 & 7 & 5 & 1. 626 & & & 5 \\
\hline 6419 & 481 & 7 & 5 & 1. 596 & & & 2 \\
\hline 6424 & 450 & 6 & 0 & 1.907 & & 5 & 1 \\
\hline
\end{tabular}

単一の球状ボイドを破壊起点とした試験片について, 円環状き裂の大きさを（1）式を用いて計算した結果を 表 1 に示す. $K_{\mathrm{IC}}$ の值は, 常圧焼結窒化ケイ素の值 ${ }^{13)}$, $4.7 \mathrm{MPa} \cdot \mathrm{m}^{\frac{1}{2}}$ を用い, ポアソン比は 0.25 として計算し た。なお, $K_{\mathrm{IC}} / \sigma \sqrt{R}$ の值は, $1.3 \sim 1.9$ の範囲にあり, 半 だ円形の表面傷に近似したときの值，1.292 ${ }^{8)}, 1.128^{9)}$ と比べて大きく，このモデルの適用が困難であることを 示唆する．算出された円環状き裂の大きさは，大部分が 約 $30 \mu \mathrm{m}$ 程度であった.これは, 本研究で用いた焼結 体の粒径が $2 \sim 3 \mu \mathrm{m}$ であるので, 粒径の $10 \sim 15$ 倍に相 当する. しかし，円環状き裂の大きさが $80 \sim 100 \mu \mathrm{m}$ と 特に大きく算出された試料も見いだされた.

曲げ試験による強度測定については，表面近傍の応力 が高くなるため, 表面付近から破壊の生ずる場合が多い. 表面近傍のボイドについては, 機械加工のときに生ずる 応力場との相互作用によりき裂が伝ぱして，円環状き裂 が異常に大きく測定された可能性がある ${ }^{14)}$. しかし, 約 $30 \mu \mathrm{m}$ のき裂については, 以下のように述べるように破 壊試験のときの荷重負荷の際に生じたと推察される.

一般に, 破壊䩲性は単結晶では小さく, 多結晶では大 きいことが知られている. Rice ら ${ }^{15)}$ は欠陥の大きさと 粒径の比が $K_{\mathrm{Ic}}$ に及ぼす影響を調へ， $\mathrm{ZnSe}$ については, 欠宿の大きさが粒径に対して $2 \sim 7$ 倍の領域で $K_{\mathrm{IC}}$ の值 が急激に変化し，その領域を超えると多結晶の $K_{\mathrm{IC}}$ にほ ぼ一致することを報告している，これは，粒径を単位と したき裂サイズが十分に小さいときには， $K_{\mathrm{Ic}}$ は単結晶 の值に相当する小さい値として測定されるが，き裂が大 きくなると， $K_{\mathrm{Ic}}$ は急激に増加して多結晶の値に近づく ことを示唆している.
$K_{\mathrm{IC}}$ のき裂長さ依存性と，荷重を徐々に増加するとき の $K_{\mathrm{I}}$ の変化を模式的に図 4 に示す．なお，この曲線の 形状は $\mathrm{ZnSe}^{15}$ についての測定結果に準じて示した。球

(a)

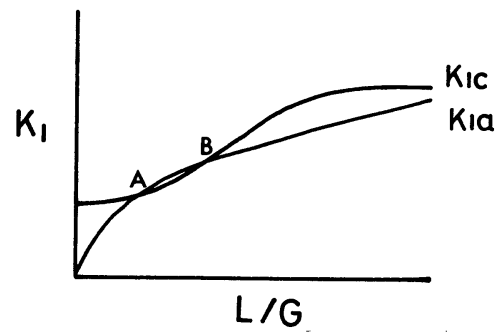

(b)

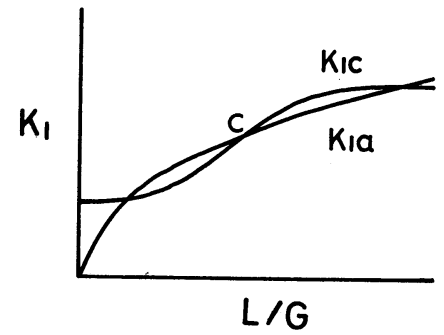

(c)

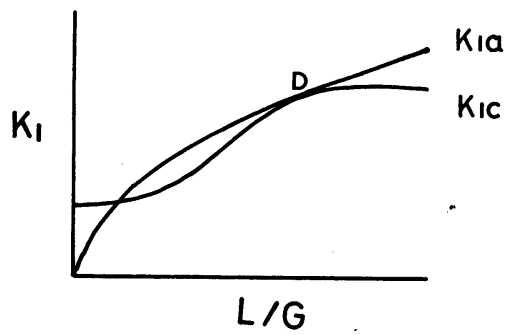

Fig. 4. Schematic indication of $K_{\text {Ic }}$ and applied stress intensity factor as a function of crack length/grain size ratio, showing crack propagation mechanism from a spherical void. 
状ボイドの内面は比較的凹凸に富む様相を呈しているの で, $1 \sim 2 \mathrm{G}$ に相当する微細き裂は存在し得るのである ろう．その微細き裂の伝ぱに要する $K_{\mathrm{I}}$ は，ほぼ単結晶 の $K_{\mathrm{IC}}$ に相当するであろうから，比較的低い応力のもと でき裂は進展を開始する。き裂が進展して大きくなると， それに伴い $K_{\mathrm{I}}$ も增大するが，それ以上に $K_{\mathrm{Ic}}$ が大きく なるので，き裂の進展は停止する（図 $4(\mathrm{a})$ ). 更に応 力が増加すると, き裂は再び進展を開始し, その大きさ は, $L / G$ の関数である $K_{\mathrm{IC}}$ と, 応力 $\sigma$ と $L$ との関数, $K_{\mathrm{I}}=Y \sigma \sqrt{L}(Y$ はき裂の形状因子）等しくなるとき の $L$ により与えられる (図 4 (b ) ). 更にき裂が進展し, 図 $4(\mathrm{c})$ のD点まで到達すると，き裂進展に伴う $K_{1}$ の増加が $K_{\mathrm{IC}}$ の増加を超えるため，急速にき裂は伝ぱし 破断に至る．そのときの $L$ がボイド周囲に発生した円 環状き裂の大きさ $L_{\mathrm{c}}$ として測定されたと考えることが できる，なお，測定された $L_{c}$ は，反応焼結窒化ケイ素 の值帛,12) より大きいが，この理由としては， $K_{\mathrm{Ic}}$ の $L / G$ 依存性に材料による相違のあること，反応焼結窒化ケイ 素のような多孔質材料については，ボイド周囲に発生し たき裂が気孔によりピニングされ進展が妨げられること などが考えられる。ボイド周囲に発生した円環状き裂の 大きさはほとんど一定であり，ボイドの大きさによる影 響は認められなかった。. Baratta ${ }^{10)}$ は，ボイドが大きい ときにその周囲に発生するき裂も大きいと指摘している が，本研究の結果には反する．なお，この指摘の根拠と

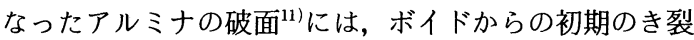
伝ぱがゆっくりとしたき裂成長により粒界を経由して生 じた領域と，その後の粒内破壊による領域が存在すると 報告されているが, 本研究に用いた常圧焼結窒化ケイ素 については，このような破面形態の変化は認められな

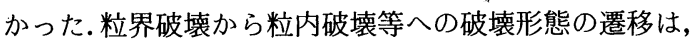
材料のみならず, 測定温度, 雾囲気, き裂伝ば速度等に も影響されると考えられるので, 必ずしも応力拡大係数 が $K_{\mathrm{IC}}$ に達したときに破壊形態の変化が生ずるとはかぎ らないであろう。たしかに，粒界破壊から粒内破壊への 遷移は, $\mathrm{ZnSe}^{16)}, \mathrm{MgF}_{2}{ }^{17)}$ などでは応力拡大係数が $K_{\mathrm{IC}}$ に達したときに生ずるが，アルミナ"11)では $K_{\mathrm{I}}>K_{\mathrm{IC}}$ の領 域で遷移が生ずると報告されている，常圧焼結窒化ケイ 素13)については，高温では $K_{\mathrm{IC}}$ 付近を境界として破壊形 態の遷移が生ずるが，常温では $K_{\mathrm{IC}}$ 付近にこのような遷 移は生じないのであろう。したがって，破面観察により ボイド周囲に発生した円環状き裂の大きさを測定した
り， $K_{\mathrm{IC}}$ を推定することは, 破壊形態の顕著な変化が生 ずる場合を除き，一般には容易ではないと考えられる.

\section{5. 総 括}

常圧焼結窒化ケイ素に球状ボイドを導入した試料を作 製し，その曲げ強さの測定と破壊起点の観察を行った。 破壊起点に見いだされる球状ボイドが大きくなると，破 壊起点の位置と曲げ強さから求めた破壊応力は低下する 傾向が認められた．円環状き裂を伴うボイドモデルを用 いて，そのき裂の大きさを算出すると約 $30 \mu \mathrm{m}$ であり， 粒径の 10 １5 倍に相当した. ボイドによる破壊機構と しては，破壊勒性のき裂長さ依存性に基づき，次のよう に考えられた。

（1）ボイド周囲にあらかじめ存在する微細き裂の進 展に要する $K_{I}$ は比較的小さいので, 破断応力以下の応 力で進展を開始する.

（２）ボイド周囲に発生した円環状き裂は，き裂伝ぱ に伴う $K_{\mathrm{IC}}$ の増大により，粒径の 10 15 倍まで荷重速 度に応じた進展をするが，その後急速に伝ぱして破断に 至る.

\section{文 献}

1) F. I. Baratta, J. Am. Ceram. Soc., 61, 490-93 (1978).

2) F. I. Baratta, ibid., 62, 527 (1979).

3) A. G. Evans, D. R. Biswas and R. M. Fulrath, ibid., 62, 101-06 (1979).

4) D. J. Green, ibid., 63, 342-44 (1980).

5) F.I. Baratta, ibid., 64, C3-4 (1981).

6) V.D. Krstic, Acta Metall., 33, 521-26 (1985).

7) A. G. Evans and R.W. Davidge, J. Nucl. Mater., 33, 249-60 (1964).

8) J. Heinrich and D. Munz, Am. Ceram. Soc. Bull., 59, 1221-22 (1980).

9) S. G. Seshadri and M. Srinivasan, J.Am. Ceram. Soc., 64, C69-71 (1981).

10) F. I. Baratta, ibid., 65, C32-34 (1982).

11) H.P. Kirchner and R. M. Gruver, ibid., 63, 169-74 (1980).

12) J. Heinrich and D. Munz, ibid., 65, C 34 (1982).

13）岡田 明, 松長正治, 赤穂義明, 宰協, 93, 426-32 (1985).

14) R.W. Rice, "Machining of Ceramics" in 'Ceramics for High-Performance Applications', Ed. by J. J. Burke, A. E. Gorum and R. N. Katz, Brook Hill, Massachusetts (1974) P. 287-343.

15) R.W. Rice, S.W. Freiman and J. J. Mecholsky, Jr., J. Am. Ceram, Soc., 63, 129-36 (1980).

16) K. R. McKinney, J. J. Mecholsky and S. W. Freiman, ibid., 63, 577-80 (1979).

17) J. J. Mecholsky, ibid., 64, 563-66 (1981). 